\title{
FOREIGN GODS IDENTIFIED IN ACTS 17:18?
}

\section{K.L . McKay}

The idea that the foreign gods referred to in Acts 17:18 included Anastasis has been widely recognised, at least from the time of Chrysostom (Aland-Nestle ad loc.), and has been incorporated into either the text or margin of some modern translations (e.g., NEB, JB). It appears to depend on the fact that the comment by

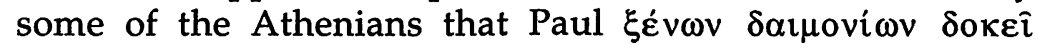

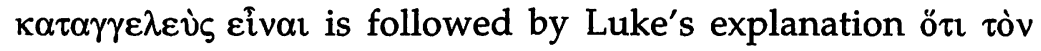

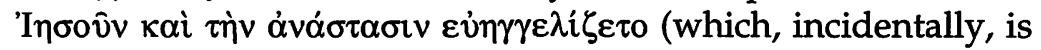
absent from the text of $\mathrm{D}$ ). The plurality of the deities and the reference to a foreign name accompanied by an abstract noun that might in that setting have been treated as a deity appear to have made it a plausible idea.

Nevertheless it does not seem to be supported by the wider context. In the summary of Paul's speech before the Areopagus Luke makes no use of the abstract noun, but refers to God revealing himself and calling men to repentance through a man whom he raised from the dead (17:30,31), after which he immediately (v. 32) recounts the Athenians' reaction

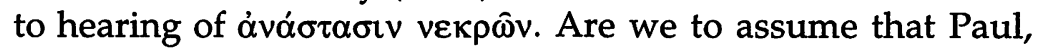
with all his consciousness of the tendency of his polytheistic audience to assume the influence of deities in all kinds of circumstances, would have introduced the idea of resurrection, either in this speech or in his preceding conversations, by means of the abstract noun $\alpha$ 'ó $\sigma \tau \alpha \sigma \iota \varsigma$ ? On the other hand, once the idea that Jesus had risen has been presented it is natural enough for the historian to use the abstract noun as a summary of the climax of the conversation or speech.

Even when writing to Christians about the resurrection Paul only occasionally uses $\dot{\alpha} v \alpha \dot{\sigma} \tau \alpha \sigma \mathrm{s}$, and then mostly as a summary of what he has already written by means of a verb, as in Romans 6:4-5 and 1 Corinthians 15:12. Moreover in Acts and the Pauline epistles (and to a certain extent elsewhere in the 
New Testament) $\dot{\alpha} v \alpha \sigma \tau \alpha \sigma \iota \varsigma$ is almost always either

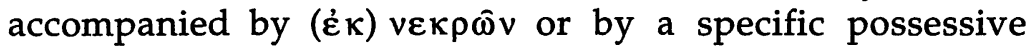

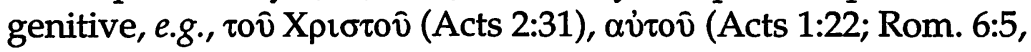
where it is understood from the parallel tov $\theta \alpha v \alpha$ q here in Acts 17 the former applies to verse 32, and to a Christian reader the latter, although unexpressed, would naturally be understood in verse 18 (Jesus and his resurrection). As I have noted elsewhere, ${ }^{1}$ the norm for references to Jesus' resurrection in the New Testament is an aorist verb, and Paul is no less concerned than other preachers and writers to emphasise that that resurrection was an event and not just an abstraction.

A further point that may be made is that the plurality of $\xi \dot{\varepsilon} v \omega v \delta \alpha \iota \mu v i \omega v$ is not likely to be significant. In general references to deities in a polytheistic society the plural tends to be used except in contexts in which one particular deity is specified or implied as uniquely relevant. Even in the fourth century B.C. Xenophon explained the accusation against

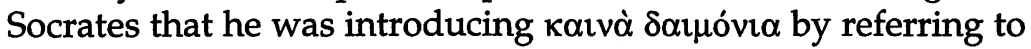

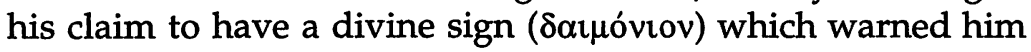
against immoral actions. ${ }^{2}$

In summary, the reported reference by the Athenians to a plurality of deities is not surprising even if only one

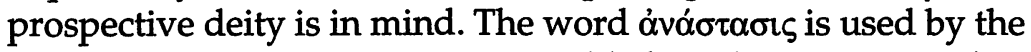
writer to summarise statements unlikely to have contained it, and this is illustrated by the account of the address to the Areopagus and its aftermath. The idea that a deity Anastasis is relevant to the context has no firm basis in the text of Acts.

\footnotetext{
${ }^{1}$ 'Some Linguistic Points in Marxsen's Resurrection Theory', Expository Times 84 (1973), 330-32.

${ }^{2}$ Memorabilia 1.2. Of course the meaning of $\delta \alpha \mu o$ viov was more vague in classical than in Hellenistic Greek: see J. Burnet's notes on Euthyphro 3b in his edition of Plato's Euthyphro, Apology of Socrates and Crito (Oxford: OUP, 1924).
} 